\title{
An Unusual Cause of Sleep Apnea: Laryngeal Schwannoma
}

\author{
Nadir Bir Uyku Apnesi Nedeni: Larenks Schwannoması
}

\author{
Hande Senem Deveci', Tülay Erden Habesoğlu', Cem Karataș', Ali Okan Gürsel', Adnan Somay², Nurver Özbay² \\ ${ }^{1}$ Fatih Sultan Mehmet Education and Research Hospital, Department of Otorbinolaryngology, Istanbul; ${ }^{2}$ Fatih Sultan Mehmet \\ Education and Research Hospital, Department of Pathology, Istanbul
}

\begin{abstract}
Laryngeal schwannomas are slow growing, quite rare benign tumors. Although they are slow growing and histologically benign, they have the potential to cause significant morbidity with laryngeal involvement. In this case report we presented a 28-year-old man with a huge laryngeal schwannoma which causes intensive snoring and obstructive sleep apnea. The tumor was totally excised by transhyoid pharyngotomy approach without any complication. There was no other documented laryngeal schwannoma case has presented with obstructive sleep apnea before.
\end{abstract}

Key words: laryngeal schwannoma; sleep apnea; transhyoid pharyngotomy

\section{ÖZET}

Larenks schwannoması oldukça nadir görülen, yavaș büyüyen benin karakterde bir tümördür ancak larengeal tutuluma bağlı olarak yüksek morbiditeye yol açma potansiyelleri vardır. Genellikle ariepiglotik plikayı veya band ventrikülü tutar. Biz bu bildiride horlama ve uyku apnesi șikayetleri ile polikliniğimize bașvuran 28 yașındaki erkek hastayı sunmaktayız. Hastanın larenks kitlesi transhiyoid faringotomi yaklașımıyla total olarak çıkarılmıș ve herhangi bir komplikasyon görülmemiștir. Literatürde uyku apnesi șikayeti ile bașvuran bașka bir vakaya rastlanmamıștır.

Anahtar kelimeler: larenks schwannomasl; uyku apnesi; transhiyoid faringotomi

\section{Introduction}

The schwannomas are benign, slow growing, encapsulated neoplasms arising from Schwann cells that comprise the myelin sheaths surrounding peripheral nerves. They occur at any age frequently in women than in men $^{1}$. Approximately $45 \%$ of these tumors present in the head and neck region but laryngeal schwannomas

Uzm. Dr. Hande Senem Deveci, Fatih Sultan Mehmet Eğitim ve Araştırma Hastanesi, E-5 Üzeri, Üst Bostanci, Ataşehir, İstanbul, Türkiye

Tel.02163721757Email.senemesen@yahoo.com

Geliş Taribi: 25.01.2015 • Kabul Tarihi: 06.05.2015 are quite rare, accounting of approximately $0.1 \%$ of all benign laryngeal tumors ${ }^{2}$. Laryngeal schwannomas arise from the internal branch of the superior laryngeal nerve $e^{3}$. Therefore they usually originated from aryepiglottic folds or false vocal cords ${ }^{3}$.

Symptoms of this lesion are related to the mass effect; they include hoarseness, globus sensation, sore throat, odynophagia, dysphagia, dyspnea, stridor, and dysphonia. Symptoms progress over months to years. Stridor and dyspnea are the late findings ${ }^{4}$. As a result of acute respiratory failure, death was reported only once in the literatures.

Obstructive sleep apnea (OSA) occurs due to enlarged tissues such as tonsils, base of tongue or soft palate, pharyngeal space narrowing, decreased muscle tone of the pharyngeal dilator muscles, or head and neck neoplasms ${ }^{6}$.

In this case report we presented a 28 -year-old man with a laryngeal schwannoma which causes snoring and sleep apnea, and treated with transhyoid pharyngotomy approach. We described the clinical picture, diagnosis and treatment management of this patient with the aid of his histopathological and radiological images.

\section{Case}

A 28-year-old male who was newly-wed admitted to our Ear-Nose-Throat Polyclinic of Fatih Sultan Mehmet Education and Research Hospital (Istanbul, Turkey) with his wife. They complained about the husband's severe snoring and sleep apneas. He did not have any significant medical history. When the history of the patient was detailed, as well dysphagia and exercise related dyspnea have been occurred. During physical examination a submucosal, well-demarcated laryngeal 


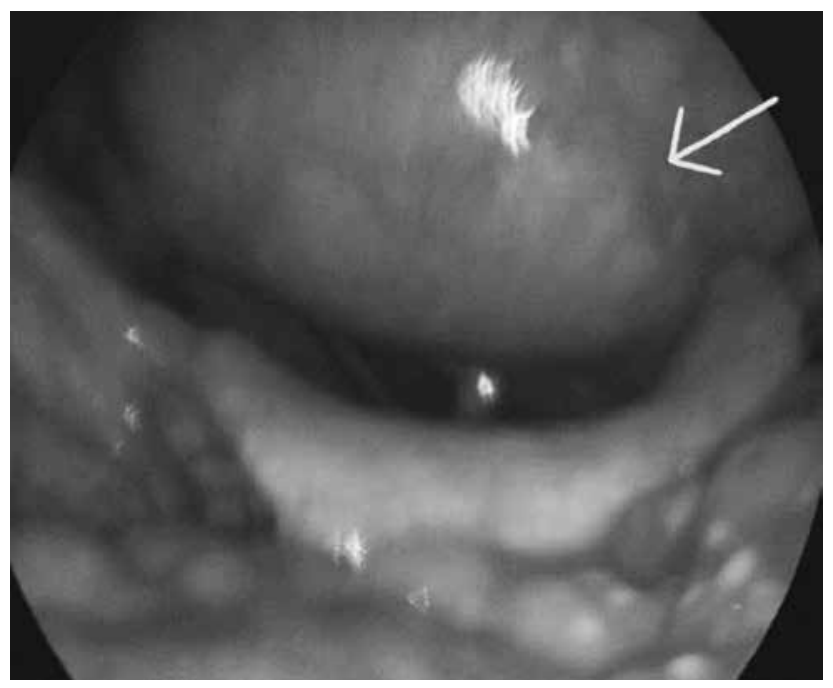

Figure 1. Preoperative laryngoscopic image of the patient. Blue arrow indicates the mass.

mass posterior to the epiglottis was noted (Fig. 1). The left vocal cord was fixed but the right vocal cord was mobile.

Magnetic Resonance Imaging (MRI) of the lesion revealed hyperintense and inhomogeneous image in contrast-enhanced scans. The lesion was expanded to the left parapharyngeal space. Both pyriform sinuses were obliterated. On the left side the lesion invaded the aryepiglottic fold and expanded to the proximal esophagus (Fig. 2).

After the imaging procedure and preoperative preparations, the patient was ready for the surgery. First of all, under the local anesthesia tracheotomy was performed and then the patient went under general anesthesia. After suspension microlaryngoscopic evaluation, at the hyoid level a $3 \mathrm{~cm}$ midline incision was performed. Through transhyoid approach we entered the pharynx. After lateralization of the epiglottis to the right side, the mass was visualized. The mass dissected from surrounding tissues and totally excised. The mass size was larger than the size of the incision, so the tumor was pushed towards pharynx with the help of a finger and removed through mouth.

Macroscopically the surgical specimen consisted of a well encapsulated white-colored tumor mass, measuring $5 \times 4 \times 2.5 \mathrm{~cm}$. At microscopic examination, the tumor was encapsulated with a fibrous capsule. In the tumor, there were densely cellular and less cellular areas with sheets of spindle cell palisading around amorphous matrix and spindle cells in myxoid stroma respectively. There was no atypia or mitosis (Fig. 3).

At the end of 6-month follow-up the patient was symptom free and we have not encountered any recurrence.
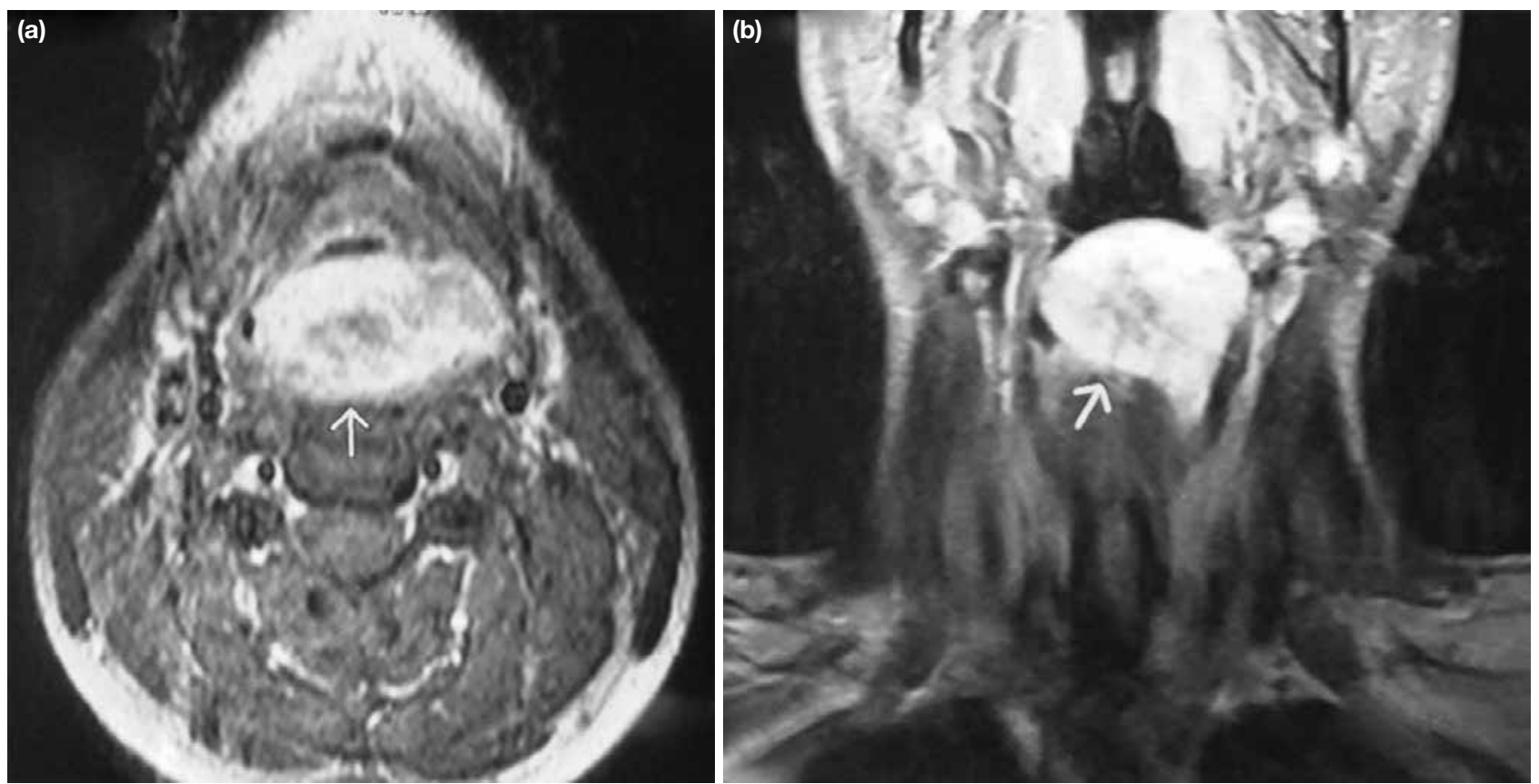

Figure 2. a, b. Coronal (a) and axial (b) MR images. Red arrow indicates the mass. 

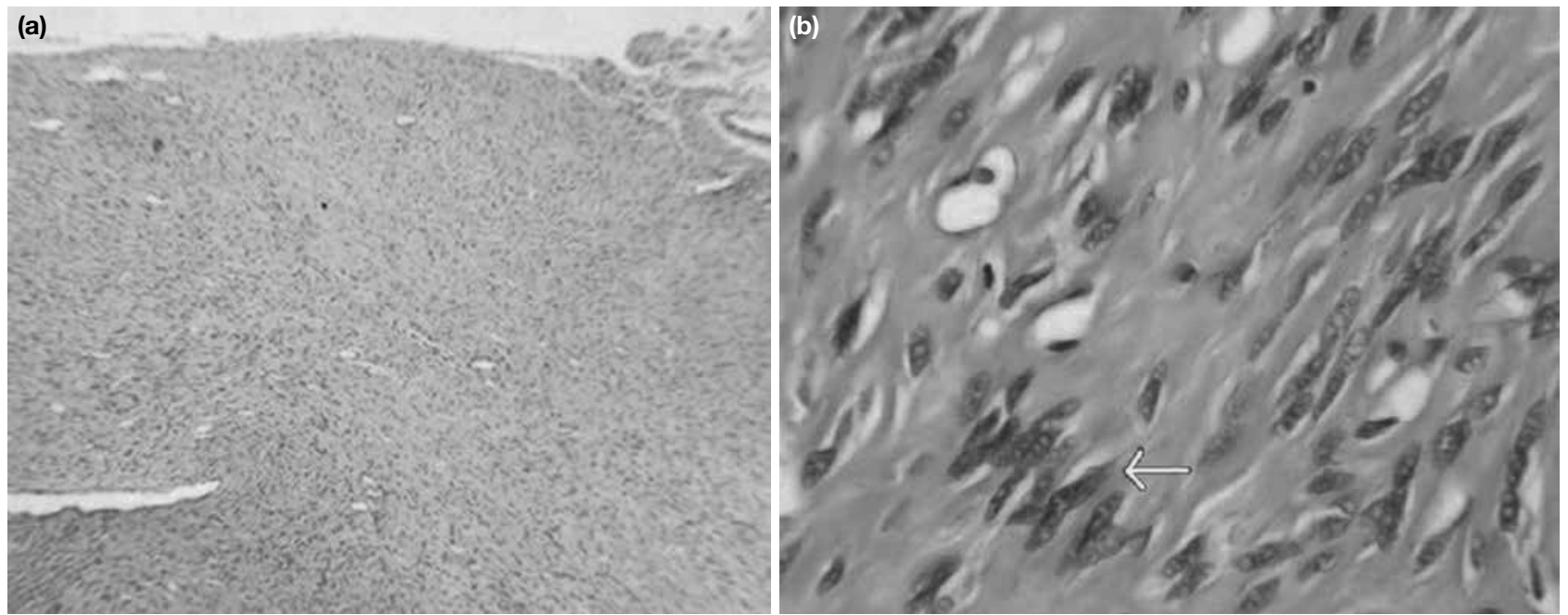

Figure 3. a, b. Stromal tumor with fibrous capsule H\&Ex40 (a). Palisading spindle cell in the stroma. Arrow indicates a palisading spindle cell H\&Ex400 (b).

\section{Discussion}

Verocay was the first to describe the tumors deriving from Schwann cells in $1908^{5}$. Since then only a few cases of laryngeal schwannomas have been reported in the literature ${ }^{2}$.

Symptoms are those associated with any slow-growing tumor of larynx, such as hoarseness and foreign body sensation during swallowing. As the tumor expands, it may cause dyspnea and stridor ${ }^{2}$. The most serious consequence of a large schwannoma reported in the literature was asphyxiation because of a "ball and valve effect" . In our report, the patient presented with snoring and sleep apneas. However, he also had dysphagia and exercise related dyspnea complaints. There was no other documented laryngeal schwannoma case which has presented with obstructive sleep apnea before.

Computed tomography (CT) scans revealed a welldefined, hypodense submucosal mass without any sign of infiltration. Small schwannomas are seen as homogeneously enhancing masses but tumors bigger than 3 $\mathrm{cm}$ in size are recognized as masses with slightly heterogeneous contrast enhancement ${ }^{7}$.

At magnetic resonance imaging (MRI), T1-weighted imaging of the mass shows variable intensity with high inhomogenenous enhancement after gadolinium injection, whereas T2-weighted images reveal a hyperintense image ${ }^{8}$. However, CT and MRI scans are not effectively diagnostic. In different being tumor also similar findings are recognized. In our case, MRI of the patient showed hyperintense and inhomogeneous image in contrast-enhanced scans and gave information about the expansion of the tumor.

A definitive diagnosis of schwannoma can only be done histologically although it may be difficult to distinguish schwannoma and neurofibroma on small samples obtained with biopsy ${ }^{4}$. Schwannomas are made up almost entirely of Schwann cells. Histologically, they appear as two types of different areas: Antoni $\mathrm{A}$ and Antoni B. Antoni A areas contain spindle-shaped cells with their nuclei aligned in a parallel-rows palisade pattern. The Antoni B type is less cellular and loosely organized, with vacuoles and spindle-shaped nuclei. Also in our case pathologically we recognized these densely cellular palisading areas (Antoni A regions), and less cellular regions with myxoid matrix (Antoni B regions) $)^{3}$.

When we reviewed the literature, the tumor size of this case was the second biggest laryngeal schwannoma ${ }^{8}$. Although the size of the tumor was very big, the patient admitted to our clinic only with snoring and sleep apnea.

Obstructive sleep apnea is caused by obstruction of the upper airways such as due to tonsillary and adenoid hypertrophy, pharyngeal space narrowing, decreased muscle tone of pharyngeal dilator muscles, or head and neck neoplasms ${ }^{6}$. The patient with OSA is rarely aware of having difficulty in breathing. It is recognized as a problem by others. Also in our case, the snoring and apnea of the patient were realized by his wife and the patient was presented to hospital because of these 
symptoms. If the OSA is not treated, cardiovascular complications, such as heart failure, myocardial infarction, arryhtmias, systemic and pulmonary hypertensions, and clinical depression risk increase ${ }^{7}$. Therefore the cause of the apnea should be eliminated. In our case to eliminate the disease, we removed the schwannoma through a transhyoid pharyngotomy approach.

Complete surgical removal is the treatment of choice. According to the size or the localization of the tumor endoscopic or external approaches could be chosen ${ }^{4}$. If the tumor size is too big for endotracheal intubation, tracheotomy followed by an external approach with median thyrotomy, lateral pharyngotomy, lateral thyrotomy or transhyoid pharyngotomy ${ }^{3}$. Furthermore, in a selected case, transrobotic approach without any tracheotomy was done in a patient ${ }^{9}$. However, this technique requires advanced experience and it is not available in each center. Wide excision of laryngeal schwannoma is necessary to prevent recurrence. Incomplete excision of the tumor may result in rapid regrowth and airway compromise ${ }^{10}$.

In our case the tumor size exceeded the resectability limits of direct laryngoscopy, so open approach was chosen. As an open approach we preferred transhyoid pharyngotomy. This mid-line approach provided a good view for complete excision of tumor safely.

\section{Conclusion}

Laryngeal schwannomas are rare, slow growing, benign neurogenic tumors usually located in the supraglottic larynx. These tumors cause globus sensation, dysphagia, dysphonia and upper airway obstruction symptoms. A definite diagnosis can only be made histologically. The only curative treatment option is complete surgical excision.

\section{Consent}

Written informed consent was obtained from the patient for publication of this case report and accompanying images.

\section{References}

1. Martin PA, Church CA, Chonkich G. Schwannoma of the epiglottis: first report of a case. Ear, Nose and Throat Journal 2002;81(9):662-3.

2. Taylor J, Stiefel M, Park SY. Schwannoma of the true vocal fold: a rare diagnosis. Ear, Nose and Throat Journal 2006;85(1):52-3.

3. Cadoni G, Bucci G, Corina L, et al. Schwannoma of the larynx presenting with difficult swallowing. Otolaryngol Head Neck Surg 2000;122:773-4.

4. Mannarini L, Morbini P, Bertino G, Gatti O, Benazzo M. Acute respiratory distress in patient with laryngeal schwannoma. Case Report Med 2012;2012.

5. Gardner PM, Jentzen JM, Komorowski RA, et al. Asphyxial death caused by a laryngeal schwannoma: a case report. Journal of Laryngology and Otology 1997;111(12):1171-3.

6. Farboud A, Pratap R, Helquist H, et al. An unusual cause of obstructive sleep apnoea. J Laryngol Otol 2009;123(11):e22.

7. Plantet MM, Hagay C, De Maulmont C, et al. Laryngeal schwannomas. Eur J Radiol 1995;21:61-6.

8. Sabat $S$, Chapman P. Radiology Quiz Case 2. Arch Otolaryngol Head Neck Surg 2010;136(6):631.

9. Kayhan FT, Kaya KH, Yilmazbayhan ED. Transoral robotic approach for schwannoma of the larynx. J Craniofac Surg 2011;22(3):1000-2.

10. Rosen FS, Pou AM, Quinn FB Jr. Obstructive supraglottic schwannoma: a case report and review of the literature. Laryngoscope 2002;112(6):997-1002. 